\title{
Rheumatic Diseases in HIV-Positive Patients in Kara (Togo)
}

Houzou Prénam ${ }^{1 *}$, Kakpovi Kodjo², Mouhari-Touré Abass ${ }^{3}$, Koffi-Tessio Viwalé ES², Fianyo Eyram ${ }^{4}$, Tagbor Komi C ${ }^{4}$, Oniankitan Owonayo ${ }^{4}$ and Mijiyawa Moustafa ${ }^{2}$

${ }^{1}$ Department of Rheumatology, University Hospital of Kara, Togo

${ }^{2}$ Department of Rheumatology, University Hospital Sylvanus Olympio of Lomé, Togo

${ }^{3}$ Department of Dermatology, University Hospital of Kara, Togo

${ }^{4}$ Department of Rheumatology, Regional Hospital of Lomé Commune, Togo

\begin{abstract}
Aim: To determine the epidemiological profile and semiological characteristics of osteoarticular manifestations in people infected with human immunodefienciency virus (HIV) in the northern region of Togo.

Patients and methods: It was a cross-sectional study conductedon the records of patients with rheumatic affection and infected with HIV, admitted in rheumatologic consultation in Kara teaching hospital (Togo) from April 2012 to February 2017.

Results: Fifty-eight patients $(70.69 \%$ female and $29.31 \%$ male) were HIV positive. Their meanage during consultation was $47.94 \pm 9.13$ years old. Traders $(37.93 \%)$ and workers of informal sector $(22.41 \%)$ were the most affected. The HIV infection was known by the patientin 45 cases before the consultation among which 41 have beenunder antiretroviral therapy (ART). The main rheumatic manifestations were: degenerative pathology of the spine (28 cases), infectious pathology ( 12 cases of which 7 were Pott's disease), reactive arthritis ( 9 cases) and osteonecrosis ( 5 cases). The mean body mass index in the 58 patients was $23.77 \mathrm{Kg} / \mathrm{m}^{2} \pm 6.44$.Fever(13.79\%)and alteration of general condition $(43.10 \%)$ were the main other signs observed. Anemia was present in $50 \%$ of cases. The erythrocyte sedimentation ratein the first hourwas higher than $50 \mathrm{~mm}$ in $62.06 \%$ of cases.
\end{abstract}

Conclusion: The degenerative pathology of the spine is common in rheumatic patients infected with HIV in Togo. However, there is an increasing part of the osteonecrosis directly related to HIV and the ART.

Keywords: HIV; Antiretroviral therapy; Rheumatism; Infection; Osteonecrosis; Togo

\section{Introduction}

In 2016, 36.7 million people have been infected with the human immunodeficiency virus (HIV) and the majority of them live in subSaharan Africa [1]. The first rheumatological manifestations of the HIV have been described since 1989 and were dominated by arthritis and arthralgia $[2,3]$. Thanks to the early initiation of the Antiretroviral Therapy (ART), the life expectancy of the carriers has virtually been normalized [4], favoring the emergence of non-transmissible chronic diseases. Besides, these people have a low quality of life when they suffer from musculoskeletal disorders, unlike those who do not [5]. In Togo, no study has been done on the rheumatic diseases among HIV-infected patientsin the northern part so far.Therefore, the objective of this study was to determine the epidemiological profile and the semiological characteristics of the osteoarticular disorders found in HIV-positive people.

\section{Patients and Methods}

It was a cross-sectional study carried out from April 2012 to February 2017 on the records of HIV-positive patients admitted in the department of rheumatology in Kara teaching hospital. Thishospital is located in the northern region of Togo, a West African country that had about 100000 infected people in 2016 and $51 \%$ of them were benefiting of ART [6]. Patients with rheumatic disease who have been screened positive before or after the first rheumatological consultation have been included in the study. The diagnosis of reactive arthritis was based on Amor criteria [7]. That of osteoarticular infection was mainly based on the radio-clinical arguments. In the absence of isolation of the germ responsible for the infection, the epidemiological arguments have helped to presumptively evoke the etiological diagnosis. The anemia was reported when the hemoglobin level was lower than $12 \mathrm{~g} / \mathrm{dl}$ in men and
$11 \mathrm{~g} / \mathrm{dl}$ in women. The data collection has been done through a field survey sheet which includes civil status, clinical, paraclinical (according to the context) and hospitalization informations of the patients. The data have been processed by Epi info7 software.

\section{Results}

Out of 2869 patients admitted during the period of study, 58 of them $(2.02 \%)$ have been infected with HIV. They were divided up into 41 women $(70.69 \%)$ and $17(29.31 \%)$ men accounting for a sex ratio of $\mathrm{M} / \mathrm{W}$ 0.41. The mean age of the patients during the rheumatological consultation was 47.94 years old \pm 9.13 (extremes: 19 to 65 years old). The meanduration of the rheumatic affection was 27.74 months (extremes: one day and 6.6 years). Traders and retailers (37.93\%), workers of the informal sector $(22.41 \%)$, civil servants $(18.97 \%)$, housewives (13.79\%) and farmers (6.90\%) have been the major occupational groups infected with HIV. The retrovirus was known in 45 patients $(77.59 \%)$ before the consultation and 41 of them $(91.11 \%)$ have been under ART. This treatment was undertaken on average 5.33 years before the consultation. The screening has been done in the office among 13 patients $(22.41 \%)$.

*Corresponding author: Dr. Houzou Prénam, Department of Rheumatology, University Hospital of Kara, Kara-Togo, Tel: 00228 98563535; E-mail: h_prenam@yahoo.fr

Received December 12, 2017; Accepted January 08, 2018; Published January 15,2018

Citation: Prénam H, Kodjo K, Abass MT, Koffi-Tessio Viwalé ES, Eyram F, et al. (2018) Rheumatic Diseases in HIV-Positive Patients in Kara (Togo). J AIDS Clin Res 9: 753. doi: 10.4172/2155-6113.1000753

Copyright: @ 2018 Prénam $\mathrm{H}$, et al. This is an open-access article distributed under the terms of the Creative Commons Attribution License, which permits unrestricted use, distribution, and reproduction in any medium, provided the original author and source are credited. 


\begin{tabular}{|l|c|}
\hline & Number (\%) \\
\hline Degenerative pathology of the spine & $28(48.27)$ \\
\hline Infectious pathology & $12(20.68)$ \\
\hline Reactive arthritis & $9(15.51)$ \\
\hline Osteonecrosis & $5(8.62)$ \\
\hline Kneeosteoarthritis & $5(8.62)$ \\
\hline HIV related arthropathy & $4(6.89)$ \\
\hline Tendinitis & $4(6.89)$ \\
\hline Carpal tunnel syndrome & $3(5.17)$ \\
\hline Gout & $2(3.44)$ \\
\hline Bone tumor & $2(3.44)$ \\
\hline Undetermined diagnosis & $3(5.17)$ \\
\hline
\end{tabular}

Table 1: Distribution of HIV-positive patients according to the rheumatic diseases.

The main rheumatic diseases found in these patients have beenthe degenerative pathology of the spine in $48.27 \%$ of cases and the infectious pathology in $20.68 \%$ of cases (Table 1). Out of the 12 patients with osteoarticular infections, seven of them had the Pott's disease; and one female patient had a tuberculous polyseritis (peritonitis, left pleurisy and oligoarthritis of the left ankle and the rights elbow and wrist). Another female patient had anosteonecrosis of the humeral head and three out of four patients had a bilateral osteonecrosis of the femoral head. We noticed the presence of the fever in $13.79 \%$ of cases and an alteration of general condition in $43.10 \%$ of cases. The mean body mass index (BMI) was $23.77 \mathrm{Kg} / \mathrm{m}^{2} \pm 6.44$. The anemia found in $50 \%$ of cases, was predominantly macrocytic $(55.10 \%)$ and normochromic (67.35\%). The meancount of the white blood cells was 5165 elements/ $\mathrm{m}^{3}$ (extremes: 2680 and 13000 elements $/ \mathrm{m}^{3}$ ) and the mean rate of the lymphocytes was 1859 elements $/ \mathrm{m}^{3}$ (extremes: 775 and 3900 elements/ $\left.\mathrm{m}^{3}\right)$. The erythrocyte sedimentation ratein the first hour was higher than $50 \mathrm{~mm}$ in $62.06 \%$ of cases. The mean hospital stay among 22 patients was 13.45 days (extremes: 3 and 72 days).

\section{Discussion}

$2.02 \%$ of rheumatic patients were carryingthe HIV. This rate is close to the one of the national HIV prevalence in Togo, which is $2.5 \%$ [6]. However, it might be undervalued due to thepatient's recruitment mode that has only been done in the rheumatological environments. A study conductedin an infectious disease clinicin Uganda has found 27\% of musculoskeletal manifestations [8]. The mean age of our patients is similar to that found by some authors [9-12]. Women and traders retailers were most affected in our study. This could be explained by the fact that in Togo, women are dominant in that sector of business with a relatively low grade level.

The degenerative pathology of the spine was the first reason for consultation by the HIV-infected patients and their mean BMI was $23.77 \mathrm{Kg} / \mathrm{m}^{2}$. The same finding was made in Burkina Faso $[13,14]$ and Thailand. This is due in part to the classical frequency of degenerative disease of the spine that remains the first motive for consultation of the rheumatic patients. The infectious pathology was dominated by Pott's disease in our study. The infectious spondylodiscitis seem to be more frequent than the infectious arthritis with banal germ during HIV infection [15]. Moreover, the association of HIV and osteoarticular tuberculosis is common in Africa [10,11], raising the problems of therapeutic treatment dueto the interactions between rifampicin and the protease inhibitors $[16,17]$. The reactive arthritis and arthropathy associated with HIV are classical manifestations among HIV-positive patients $[2,3,8,9,18,19]$. All the same, the treatment of this inflammatory rheumatism remains a challenge dominated by the interactions between theART and the immunosuppressive treatment $[20,21]$. Unlike the
West, where they appear as frequently associated with HIV and its treatment [22-26], no case of connectivity and vasculitis was found in our study.The rarity of these affections in the black race would be the main reason. The osteonecrosis are therefore now associated with HIV and/or with its treatment $[9,27-29]$ and they tend to be bilateral in our study. Tendinopathies and carpal tunnel syndrome are also common during HIV infection [10-12,30]. The Macrocytic anemiapredominated in our patients and would be related to stavudine that was widely used in the protocols of ART in Togo. The moderate acceleration of the ESR has been described by other authors $[8,10]$.

\section{Conclusion}

Rheumatic affections are common in HIV-infected patients. The extension in their life expectancy thanks to the new ART has led them to consult more often for diseases unrelated to HIV amongwhich the degenerative pathology of the spine is the leading diseasein the Northern region Togo. However, the iatrogenic complications, dominated by osteonecrosis in Africa, pose additional challenges to be met.

\section{References}

1. http://www.unaids.org/fr/resources/fact/Seet

2. Winchester R, Bernstein D, Fischer H, Enlow R, Solomon G (1987) The cooccurrence of Reiter's syndrome and acquired immunodeficiency. Ann Intern Med 106: 19-26.

3. Berman A, Robredo G, Spindler A, Lasala ME, Lopez H, et al. (1991) Rheumatic manifestations in populations at risk for HIV infection: The added effect of HIV. J Rheumatol 18: 1564-1567.

4. The Antiretroviral Therapy Cohort Collaboration (2017) Survival of HIV-positive patients starting anti-retroviral therapy between 1996 and 2013 : A collaborative analysis of cohort studies. Lancet 4: e349-e356.

5. Kole AK, Roy R, Kole DC (2013) Musculoskeletal and rheumatological disorders in HIV infection: Experience in a Tertiary Referral Center. Indian J Sex Transm Dis 34: 107-112.

6. http://www.unaids.org/fr/regionscountries/countries/togo

7. Amor B, Dougados M, Mijiyawa M (1990) Criteres de classification des Spondylarthropathies. Rev Rhum Mal Osteoartic 57 : 85-89.

8. Kaddu-Mukasa M, Ssekasanvu E, Ddumba E, Thomas D, Katabira ET (2011) Rheumatic manifestations among HIV positive adults attending the infectious disease clinical Mulago hospital. Afr Health Sci 11: 24-29.

9. Yao Q, Frank M, Glynn M, Altman RD (2008) Rheumatic manifestations in HIV 1 infected in-patients and literature review. Clin Exp Rheumatol 26: 799-806.

10. Cisse I, Gado S, Pamanta S, Kodio B, Sanogo Z, et al. (2009) Manifestations ostéoarticulaires associées à l'infection par le VIH/SIDA au CHU du Point G. Rev Rhum 79:1068.

11. Kakpovi K, Fianyo E, Houzou P, Koffi-Tessio A, Tagbor K, et al. (2015) Séroprévalence de l'infection à $\mathrm{VIH}$ dans le service de rhumatologie du $\mathrm{CHU}$ SylvanusOlympio de Lomé (Togo). Rev Rhum 82: A181.

12. Bileckot R, Ndamba BB, Diafouka M, Nzounza P (2010) Manifestations rhumatologiques au cours de l'infection à $\mathrm{VIH}$ chez les patients sous traitement antirétroviral. La Lettre du Rhumatologue 361: 26-29.

13. Ouédraogo $D D$, Lompo $C P$, Tiéno $H$, Bognounou $R$, Diendéré $A E$, et al (2010) Manifestations rhumatologiques des personnes vivant avec le virus de l'immunodéficience humaine, traitées par antirétroviraux: Etude prospective de 366 malades au Burkina Faso. Med Trop 70: 345-348

14. Chiowchanwisawakit $P$, Koolvisoot A, Ratanasuwan W, Suwanagool S (2005) Prevalence of rheumatic disease in HIV infected Thai patients. J Med Assoc Thai 88: 1775-1781.

15. Busch VJ, Regez RM, Heere B, Willems WJ (2007) Osteoarticular infections in HIV-infected patients: 23 cases among 1,515 HIV-infected patients. Acta Orthopaedica 78: 786-790.

16. Aaron L, Saadoun D, Calatroni I, Launay O, Mémain N, et al. (2004) Tuberculosis in HIV-infected patients: A comprehensive review. Clin Microbio Infect 10: 388-398. 
Citation: Prénam H, Kodjo K, Abass MT, Koffi-Tessio Viwalé ES, Eyram F, et al. (2018) Rheumatic Diseases in HIV-Positive Patients in Kara (Togo). J AIDS Clin Res 9: 753. doi: 10.4172/2155-6113.1000753

17. Lalloo UG, Pillay S (2008) Managing tuberculosis and HIV in sub-Sahara Africa. Curr HIVIAIDS Rep 5: 132-139.

18. Ntsiba H, Lamini N (2004) Les manifestations articulaires du VIH sont-elles des spondylarthropathies? Rev Rhum 71: 584-587.

19. Bileckot R, Koubemba G, Nkoua JL (1999) Etiology of oligoarthritis in equatorial Africa: A retrospective study of 80 cases in Brazzaville, Congo. Rev Med Interne 20: 408-411.

20. Adizie T, Moots RJ, Hodkinson B, French N, Adebajo AO (2016) Inflammatory arthritis in HIV positive patients: A practical guide. BMC Infect Dis 16: 100.

21. Fox C, Walker-Bone K (2015) Evolving spectrum of HIV-associated rheumatic syndromes. Best Pract Res Clin Rheumatol 29: 244-258.

22. Yen YF, Chuang PH, Jen IA, Chen M, Lan YC, et al. (2017) Incidence of autoimmune diseases in a nationwide HIVIAIDS patient cohort in Taiwan, 20002012. Ann Rheum Dis 76: 661-665.

23. Louthrenoo W (2008) Rheumatic manifestations of human immuno deficiency virus infection. Curr Opin Rheumatol 20: 92-99.

24. Zhang X, Li H, Li T, Zhang F, Han Y (2007) Distinctive rheumatic manifestations in 98 patients with human immuno deficiency virus infection in China. J Rheumatol 34: 1760-1764.

25. Calabrese LH, Kirchner E, Shrestha R (2005) Rheumatic complications of human immunodeficiency virus infection in the era of highly active anti retroviral therapy: Emergence of a new syndrome of immune reconstitution and changing patterns of disease. Semin Arhtritis Rheum 35: 166-174.

26. Walker-Bone K, Doherty E, Sanyal K, Churchill D (2016) Assessment and management of musculo skeletal disorders among patients living with HIV. Rheumatology 56: 1648-1661.

27. Reveille JD, Williams FM (2016) Infection and musculoskeletal conditions: Rheumatologic complications of HIV infection. Best Pract Res Clin Rheumatol 20: $1159-1179$.

28. Mehta P, Nelson M, Brand A, Boag F (2013) A vascular necrosis in HIV. Rheumatol Int 33: 235-238.

29. Whitlock GG, Herbert S, Copas A, Gilson R, Ainsworth JG (2013) A vascular necrosis in HIV patients: A case-control study. Int J STD AIDS 24: 799-803.

30. Njobvu P, Mc Gill P (2006) Soft tissue rheumatic lesions and HIV infection in Zambians. J Rheumatol 33: 2493-2497. 